\title{
Relationships between frost hardiness, root growth potential, and photosynthesis of nursery-grown white spruce seedlings
}

\author{
Sylvie Carles $•$ Mohammed S. Lamhamedi . \\ Debra C. Stowe • Pierre Y. Bernier • Linda Veilleux • \\ Hank A. Margolis
}

Received: 28 March 2011 /Accepted: 11 September 2011 / Published online: 8 November 2011

(C) INRA and Springer-Verlag, France 2011

\begin{abstract}
- Context Root growth is a characteristic to which nursery personnel is particularly attentive. The increase in root growth of white spruce seedlings in the autumn relies on the current season's photosynthates. Needle hardening or a decrease in the mass of photosynthetically active foliage as a result of early frost may negatively affect the seedling's photosynthetic capacity and its ability to fuel root growth.

- Aims This study evaluated the relationship between cold hardiness, root growth potential, and photosynthesis of 2year-old white spruce seedlings.

- Methods At the end of their second growing season under standard cultural practices in a forest nursery, seedlings were hardened under natural conditions of photoperiod and temperature. After being subjected to artificial freezing tests on four sampling dates during the fall, the seedlings were compared for cold tolerance and recovery of gas exchange. - Results The effect of artificial freezing treatments on seedling photosynthesis varied with frost intensity and degree
\end{abstract}

Handling Editor: Gilbert Aussenac

S. Carles $(\bowtie) \cdot$ D. C. Stowe $\cdot$ H. A. Margolis

Centre d'étude de la forêt (CEF), Faculté de foresterie,

de géographie et de géomatique, Pavillon Abitibi Price, Université Laval,

2405 rue de la Terrasse,

Québec, QC G1V 0A6, Canada

e-mail: sylvie.carles@sbf.ulaval.ca

M. S. Lamhamedi $\cdot$ L. Veilleux

Direction de la Recherche Forestière, Forêt Québec, ministère des Ressources naturelles et de la Faune,

2700 rue Einstein,

Québec, QC G1P 3W8, Canada

\section{P. Y. Bernier}

Natural Resources Canada, Canadian Forest Service, 1055 rue du P.E.P.S, P.O. Box 10380, Succ. Sainte-Foy, Québec, QC G1V 4C7, Canada of needle hardening. The mass of new roots formed over a 21-day cultivation test period following the freeze tests was positively related to the photosynthetic capacity of the seedlings and negatively related to the proportion of damaged needles.

- Conclusion These results imply that autumnal cold damage to needles directly affects seedling root growth and emphasize the importance of maintaining seedlings in an environment favorable for photosynthesis during the fall to promote root growth.

Keywords Picea glauca $\cdot$ Cold damage $\cdot$ Hardening $\cdot$ Root growth $\cdot$ Photosynthesis

\section{Introduction}

Seedling quality is generally determined by outplanting performance (Landis 2010) and is linked to a seedling's capacity to rapidly establish good contact between its roots and the surrounding soil (Grossnickle 2005). Therefore, root system development is a characteristic to which nursery personnel must be particularly attentive. In Quebec, seedlings must meet 25 rigorous quality standards before being shipped to plantation sites (Veilleux et al. 2010). According to the first of these criteria, root systems of containerized seedlings must be sufficiently developed and possess adequate root plug cohesion to permit handling and transporting of the seedlings with minimal or no root damage (Veilleux et al. 2010). Boreal climate is characterized by a short growing season and extremely cold winter temperatures (Müller 1982). Since they are not produced under greenhouse conditions, large white spruce (Picea glauca [Moench] Voss) seedlings must, therefore, meet strict morphological criteria within two short growing seasons as per official guidelines in Quebec (Margolis 1987). Moreover, since they are kept outside during winter, shoots and roots of containerized white spruce 
seedlings are susceptible to damage by both early and late frosts (Bigras and Dumais 2005).

Boreal conifers have developed physiological mechanisms that enable them to alternate growth and rest periods in phase with the climate (Bigras et al. 2001). Cold hardiness can be defined as the physiological state that enables them to tolerate subzero temperature without damage (Grossnickle 2000; Levitt 1980). The passage from a nonhardy state to a hardy one is called cold hardening (Sakai and Larcher 1987) or cold acclimation (Bigras et al. 2001) and is observed during the fall. Shoot cold hardening consists of two stages. The first stage is induced by a shortening of the photoperiod (Grossnickle 2000; Silim and Lavender 1994) and is concomitant with seedling height growth cessation. The photoperiod threshold for initiating cold hardening in white spruce is of about $14 \mathrm{~h}$ but can vary between populations (Nienstaedt and Zasada 1990). After this first stage, cold hardiness progressively increases in response to low temperatures (Grossnickle 2000; Silim and Lavender 1994). Once hardened, white spruce needles can tolerate temperatures below $-65^{\circ} \mathrm{C}$ (Silim and Lavender 1994). By contrast, root growth cessation and cold hardening are not influenced by photoperiod but only by substrate temperature (Bigras and D'Aoust 1993; Bigras and Dumais 2005). As long as the substrate temperature remains higher than $5^{\circ} \mathrm{C}$ (Bigras and D'Aoust 1993), root growth of boreal tree species continues even though shoots are dormant (Bigras and Dumais 2005). Once hardened, white spruce roots can tolerate temperatures below $-17^{\circ} \mathrm{C}$ (Bigras and D'Aoust 1992).

This study is part of a larger project whose aim was to identify the particular factors that influence root growth and hardening in nursery-grown white spruce seedlings. Among other results, these studies established that a substrate water content of $30 \%(v / v)$, or above, does not influence root growth of 1-year-old (Lamhamedi et al. 2001) or 2-year-old (Stowe et al. 2010) white spruce seedlings and a substrate water content as high as $55 \%(v / v)$ neither artificially prolongs white spruce seedling root growth nor impairs root hardening in the autumn (Carles et al. 2008; Lamhamedi et al. 2001). The present study complements the results of Carles et al. (2008) by characterizing the relationship between cold hardiness, root growth potential, and photosynthesis of 2-year-old white spruce seedlings during autumn.

The period of increased root growth of white spruce seedlings in the autumn (Johnson-Flanagan and Owens 1985) coincides with the cessation of height growth and initiation of bud formation when the seedlings are still physiologically active (Islam et al. 2009) and that the products of photosynthesis are translocated towards belowground sinks (van den Driessche 1987). Autumn frosts may significantly decrease leaf or needle area, thus negatively affecting the seedling's photosynthetic capacity and its ability to initiate new roots. During hardening, the photosynthetic apparatus of coniferous species gradually adapts to decreasing temperatures (Öquist and Huner 2003; Vidaver et al. 1989). A decrease in photosynthesis or the mass of photosynthetically active foliage as a result of early frost may reduce root initiation and growth, therefore compromising root plug cohesion. We have limited knowledge about the recovery of photosynthetic activity in white spruce seedlings subjected to autumnal frost at different times during the hardening period. We also know very little about the effect of photosynthetic recovery on the initiation of new roots and whether or not hardening level and/or the amount of photosynthetically active foliage affects the recovery.

The objectives of the present study were to evaluate whether (1) the loss of photosynthetic activity following the application of different intensities of artificial freezing treatments affected the initiation of new roots in white spruce seedlings and (2) the level of root initiation was influenced by the hardening level of the seedlings.

\section{Material and methods}

\subsection{Seedling material}

White spruce seeds were sown on 24 May 2001 in IPL 25$350 \mathrm{~A}$ air-slit containers (25 cavities per container, $350 \mathrm{~cm}^{3}$ per cavity; IPL ${ }^{\circledR}$, Saint-Damien, Québec) filled with a peat/ vermiculite (3:1) growing medium. The seedlings were cultivated in an unheated polyethylene tunnel at a private forest nursery located in Saint-Louis-de-Blandford, Québec $\left(46^{\circ} 25^{\prime} \mathrm{N}, 72^{\circ} 00^{\prime} \mathrm{W}\right)$ and subjected to standard cultural practices during their first year of growth (Stowe et al. 2010). Containers were raised on pallets during the growing season and placed on the ground for overwintering. As it is customary, the tunnel was left uncovered between October 2001 and April 2002 and a thick layer of natural snow covered the seedlings during the winter (Margolis 1987).

On 30 April 2002, at the beginning of the seedling second growing season, the tunnel cover was reinstated so that water inputs could be controlled for a complementary study of the impact of increased irrigation efficiency on the hardening and cold tolerance of 2-year-old containerized white spruce seedlings (Carles et al. 2008; Stowe et al. 2010). A completely randomized block experiment, consisting of four repetitions, was installed along the length of one side of the tunnel. Each block contained 84 containers with a buffer zone of 28 containers between adjacent blocks. Irrigation uniformity was assured through the use of a mobile boom irrigation system (Aquaboom, Harnois Industries, Saint Thomas de Joliette, Québec; coefficient of uniformity 95\%). Substrate fertility was monitored and adjusted biweekly using Plantec (Girard et al. 2001), a fertilization-scheduling software which takes into account both seedling growth parameters and mineral 
nutrient needs when determining substrate fertility. By the end of the second growing season (10 October 2002), each seedling had received a total of $157.4 \mathrm{mg}$ nitrogen, $42.7 \mathrm{mg}$ phosphorus, and $56.7 \mathrm{mg}$ potassium.

\subsection{Bud formation}

Formation of apical buds was monitored on a weekly basis for 300 seedlings ( 3 containers of 25 seedlings per block), beginning on 1 August 2002. The seedlings were considered to have initiated buds once the exterior bud scales were pale yellow in color (Bigras and D'Aoust 1993). All the seedlings had formed buds by 16 September 2002. On this date, the average height, diameter, and dry mass of the seedlings were $33.62 \mathrm{~cm}( \pm 0.47), 6.55 \mathrm{~mm}( \pm 0.05)$, and $7.40 \mathrm{~g}( \pm 0.13)$, respectively $(n=90)$. Foliar nutrient concentrations measured on the same date were $2.42 \%( \pm 0.02), 0.28 \%( \pm 0.002)$, and $0.69 \%( \pm 0.004)$ for nitrogen, phosphorus, and potassium, respectively.

\subsection{Environmental conditions in the nursery}

Temperatures were measured at $2 \mathrm{~m}$ above the ground, at the substrate surface, and within the rhizosphere between July and October 2002 and recorded at 15-min intervals using a datalogger (model CR10X, Campbell Scientific Corp., Edmonton, Alberta) (see Fig. 2 in Carles et al. 2008). Figure 1 presents the daily maximum, mean, and minimum temperatures $2 \mathrm{~m}$ above the ground, chilling sum accumulation, and photoperiod length at the nursery between 1 August and 28 October. Chilling sum was calculated by cumulating the number of

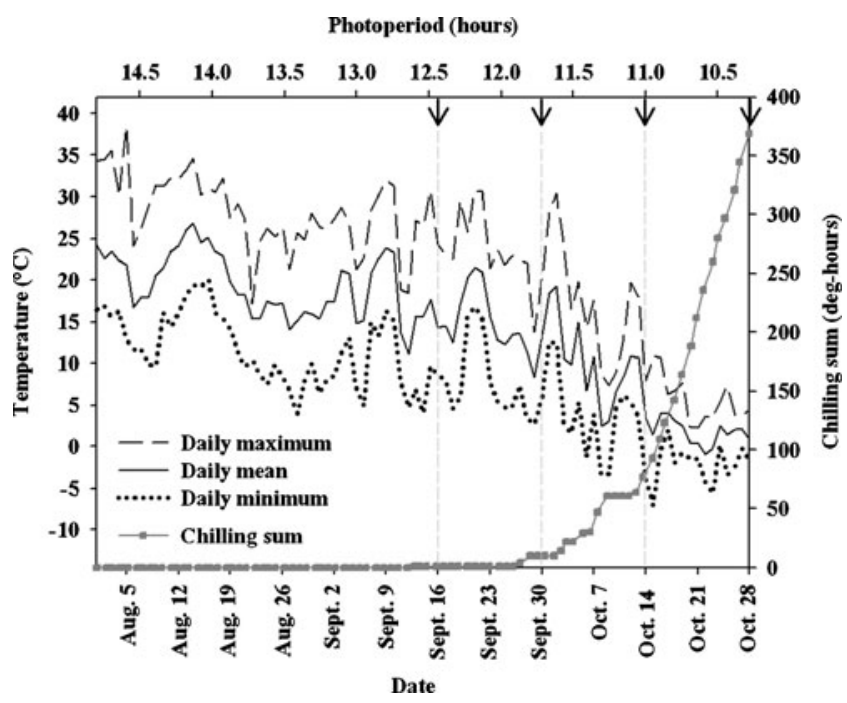

Fig. 1 Variation in daily minimum, mean, and maximum air temperatures $2 \mathrm{~m}$ above the ground, photoperiod length, and number of accumulated chilling hours $\leq 4.4^{\circ} \mathrm{C}$ from 1 August to 28 October 2002 at a forest nursery located in Saint-Louis-de-Blandford, QC, Canada $\left(46^{\circ} 25^{\prime} \mathrm{N}, 72^{\circ} 00^{\prime} \mathrm{W}\right)$ hours during which air temperature was below $4.4^{\circ} \mathrm{C}$ (Timmis et al. 1994). During the sampling period (16 September-28 October), the average daily air temperature was below $0^{\circ} \mathrm{C}$ on two occasions, 22 October $\left(-1^{\circ} \mathrm{C}\right)$ and 23 October $\left(-0.2^{\circ} \mathrm{C}\right)$. The minimum average daily substrate temperature was $0.5^{\circ} \mathrm{C}$. Air temperature dropped below freezing for the first time during the night of 6 October (minimum $=-1.1{ }^{\circ} \mathrm{C}$ ). The lowest air temperature during the experimental period was recorded on the morning of 15 October $\left(-7^{\circ} \mathrm{C}\right)$. On the same morning, the temperatures at the substrate surface and in the rhizosphere were $-4.6^{\circ} \mathrm{C}$ and $2.2^{\circ} \mathrm{C}$, respectively. Photoperiod length declined from $14 \mathrm{~h} 48 \mathrm{~min}$ on 1 August to $10 \mathrm{~h} 17 \mathrm{~min}$ on 28 October. Chilling sum reached 1, 10, 77 and 369 degree-hours on 16 September, 30 September, 14 October, and 28 October, respectively.

\subsection{Artificial freezing treatments}

Several tests were conducted during the hardening period in September and October 2002 to determine the seedlings' level of tolerance to autumnal frost. When the first freezing treatment was applied, all seedlings had completed bud formation, i.e., they had pale yellow exterior bud scales. Consequently, all seedlings were considered to be at the same phenological stage. These artificial freezing tests are described in detail in Carles et al. (2008). Artificial freezing treatments were applied to intact seedlings with root plugs within $24 \mathrm{~h}$ of their harvest on 16 September, 30 September, 14 October, and 28 October 2002 using a programmable freezer (model T20RS, Tenney Environmental Inc., Williamsport, PA, USA). A total of 240 seedlings from 3 containers per block were harvested on each sampling date. The $350-\mathrm{cm}^{3}$ root plugs were maintained intact around the root system to simulate nursery conditions of container-grown seedlings. Also, the containers were immersed in water for $2 \mathrm{~h}$ prior to each freeze test in order to simulate the locally common practice of saturating the container substrate in the autumn to prevent plant loss from root freezing. In preparation for electrolyte leakage tests, the apices (last $5 \mathrm{~cm}$ of the terminal shoots, including the entire apical bud) of two seedlings per container from three containers per block were severed and placed in $125 \mathrm{ml}$ Erlenmeyer flasks. One flask was used for each temperature. The 60 seedlings per block were divided into 15 groups of 4 seedlings each and placed in separate airtight plastic bags. A cluster of three groups (three plastic bags) per block was subjected to one of five temperatures: $t_{0}=+4^{\circ} \mathrm{C}, t_{1}=-4^{\circ} \mathrm{C}$, $t_{2}=-8^{\circ} \mathrm{C}, t_{3}=-12^{\circ} \mathrm{C}$, and $t_{4}=-20^{\circ} \mathrm{C}$. The apices and the seedlings subjected to the control temperature $\left(t_{0}=+4^{\circ} \mathrm{C}\right)$ were kept in a refrigerator. The artificial freezing treatments $\left(t_{1}, t_{2}, t_{3}\right.$, and $\left.t_{4}\right)$ were administered in a freezer equipped with a programmable controller (model Versa Tenn II, Union, NJ, USA). Except for the apices and the seedlings 
subjected to the control temperature, all of the apices and the bagged seedlings were put in the freezer where they were first chilled to $-2^{\circ} \mathrm{C}$ for $40 \mathrm{~h}$ to assure that all of the substrate in the root plugs attained a frozen state (Zhu et al. 2002). The temperature was then gradually decreased at a rate of $2^{\circ} \mathrm{C} / \mathrm{h}$ (Levitt 1980). Once the air temperature around the shoot tissue reached one of the target levels $\left(-4^{\circ} \mathrm{C},-8^{\circ} \mathrm{C},-12^{\circ} \mathrm{C}\right.$, or $\left.-20^{\circ} \mathrm{C}\right)$, it was maintained constant for $1 \mathrm{~h}$. When the six Erlenmeyer flasks per block and the three bags of four seedlings each reached the particular target temperature, they were removed from the freezer and placed in a refrigerator at $+4^{\circ} \mathrm{C}$. Because the substrate has not been removed around the roots and has been saturated with water prior to freezing, rhizosphere temperatures were always several degrees higher than those underwent by the shoot tissues. During the freeze treatments, the rhizosphere temperatures were $+4^{\circ} \mathrm{C}$ (control), $-1^{\circ} \mathrm{C},-4^{\circ} \mathrm{C},-8^{\circ} \mathrm{C}$, and $-18^{\circ} \mathrm{C}$, whereas air temperatures around the shoots were $+4^{\circ} \mathrm{C},-4^{\circ} \mathrm{C},-8^{\circ} \mathrm{C}$, $-12^{\circ} \mathrm{C}$, and $-20^{\circ} \mathrm{C}$ during the same treatments.

The damage caused by the artificial freezing treatments was quantified as described below.

\subsubsection{Index of injury}

The electrical conductivity was evaluated according to the procedure described by Colombo et al. (1984). Cold hardiness to a given temperature $(t)$ was expressed using an index of injury $\left(I_{\mathrm{t}}\right)$ calculated on a percentage basis (Flint et al. 1967). A high $I_{\mathrm{t}}$ signifies a low level of cold tolerance (Flint et al. 1967).

\subsubsection{Root water loss tests}

The percentage of water lost from the root systems (RWL) of six seedlings per block per temperature was evaluated as the difference in weight of the saturated tissues before and after being sealed in a pressure chamber (model 600, PMS Instrument Co., Corvallis, OR, USA) for $10 \mathrm{~min}$ at $1.5 \mathrm{MPa}$ (Coursolle et al. 2000; Ritchie 1990).

\subsubsection{Recovery of gas exchange, initiation of new roots, and shoot damage}

Once the artificial freezing tests had been completed, 6 seedlings per block per temperature (120 seedlings) were repotted into 3-L plastic pots filled with a moist peat/ vermiculite $(3: 1)$ mixture and subsequently grown under optimal greenhouse conditions for 21 days (photoperiod= $14 \mathrm{~h}$; temperature day/night $=25^{\circ} \mathrm{C}: 18^{\circ} \mathrm{C} \pm 3^{\circ} \mathrm{C}$ ). Highpressure sodium lamps (400 W, P.L. 780, P.L. Lighting Systems) were used between 1600 and 2100 hours to guarantee a 14-h photoperiod. During each of the four cultivation tests, the seedlings were watered regularly, but were not fertilized.

Repeated gas exchange measurements were made on three seedlings per block per temperature on the 2nd (D2), 4th (D4), 11th (D11), and 21st (D21) day after repotting. The same lateral branch was used for the series of measurements. A branch containing needles of the same age was selected for each of the seedlings. Gas exchange was quantified using an open path system (model LCA-4, ADC Co., Hoddesson, UK) equipped with a conifer chamber (model PLC4-C, ADC Co., Hoddesson, UK). Saturated light levels $\left(1,000 \mu \mathrm{mol} \mathrm{m} \mathrm{m}^{-2} \mathrm{~s}^{-1}\right)$ were maintained through the use of a portable light unit attached to the foliar chamber (model PLU-002, ADC Co., Hodesson, UK) which was attached to the foliage chamber.

The surface area of the needles on each branch used for the gas exchange measurements was determined at the end of the 21-day cultivation test by volume displacement as described in Stowe et al. (2010). A regression equation linking the needle surface area to needle dry mass permitted us to estimate the surface area of the needles that fell off the branch or were damaged during the repeated gas exchange measurements. The photosynthetic capacity $\left(A_{\max }\right)$, substomatal $\mathrm{CO}_{2}$ concentration $\left(C_{\mathrm{i}}\right)$, and stomatal conductance to water vapor $\left(g_{\mathrm{sw}}\right)$ were corrected as a function of the actual surface area of each sample used for gas exchange measurements. To quantify the total photosynthetic capacity during the cultivation test, we integrated the evolution of photosynthesis over the 21-day period. The integral $\left(I_{A_{\max }}\right)$ was calculated according to the equation used for other physiological variables by Myers (1988).

Twenty-one days after repotting, the substrate was gently washed from the seedlings' root systems. All of the fine white roots $(\geq 1 \mathrm{~cm}$ long) that had developed during the cultivation test were subsequently removed, dried, and weighed. The older, lignified roots, formed prior to the cultivation test, were also dried and weighed. The initiation of new roots was quantified for each cultivation test by two different methods: (1) by the dry mass of the new white roots $\left(R_{\mathrm{w}}\right)$ (Oliet et al. 2011) and (2) by the ratio of new white root mass $\left(R_{\mathrm{w}}\right)$ to total seedling root mass $\left(R_{\mathrm{t}}\right),\left(R_{\mathrm{w}} / R_{\mathrm{t}}\right)$.

We also collected dead foliage that had fallen off of the branches during the cultivation test. At the end of the 21day period, shoot damage resulting from the freeze treatments was quantified by calculating the ratio of the dry mass of the dead needles $\left(N_{\mathrm{d}}\right)$ to the total needle dry mass $\left(N_{\mathrm{t}}\right)$ (i.e. $\left.N_{\mathrm{d}} / N_{\mathrm{t}}\right)$.

\subsection{Experimental design and statistical analyses}

A strip-strip plot design was used for this experiment (Bernier-Cardou and Bigras 2001). The main plots consisted of the four sampling dates (experimental unit $=$ three 
containers per block), while the subplots were associated with the five artificial freezing temperatures (experimental unit=three groups of four seedlings). Each of the 3 containers sampled per block and per date was randomly chosen among the 84 containers of a block, brought back from the nursery, and put in cold storage $\left(+4^{\circ} \mathrm{C}\right)$ for 1 night. The next day, containers were immersed in water for $2 \mathrm{~h}$, after which 20 seedlings were randomly chosen in each container and split into 5 groups of 4 seedlings that were then placed in airtight plastic bags. Each bag was then randomly assigned to one of the five test temperatures. The operation was repeated for each of the 12 containers sampled per date.

The analyses were performed using PROC MIXED (SAS Institute Inc., Cary, NC, USA) (Bernier-Cardou and Bigras 2001; Littell et al. 1996). Date and temperature effects, as well as their interactions, were considered as fixed effects, whereas the effects of blocks and their interactions were considered as random effects. The random part of the model was reduced following the method described by Bernier-Cardou and Bigras (2001). Simple effects were considered significant at a threshold of $5 \%$ and double interactions at a threshold of $1 \% . R_{\mathrm{w}} / R_{\mathrm{t}}$ was $\log$ transformed to meet the statistical assumptions of normality and homoscedasticity, though data were reported as original means with standard errors (Oliet et al. 2011).

In the case of the variables evaluating the damage caused by the artificial freezing treatments $\left(\mathrm{RC}, N_{\mathrm{d}} / N_{\mathrm{t}}, \mathrm{RWL}\right.$, and $R_{\mathrm{w}} / R_{\mathrm{t}}$ ), if a date $\times$ temperature interaction proved to be significant at $1 \%$, an analysis by date was conducted both to better characterize the interaction and to clarify the gradual progression of seedling hardening with respect to the freezing temperatures used for the evaluation (Milliken and Johnson 1984). For each date, a Fischer test was used to determine if at least one difference existed among the five temperatures. If the test was found to be significant, a Student's $t$ test was conducted to compare the temperatures two by two (SLICE and PDIFF options of the LSMEANS statement of PROC MIXED) (Littell et al. 1996). The data from the photosynthetic measurements were analyzed using the REPEATED option of PROC MIXED.

To establish a relationship between the initiation of new white roots and photosynthetic activity during the cultivation tests, we took into account the integral of the curve describing the evolution of photosynthetic activity during the cultivation test periods $\left(I_{A_{\max }}\right)$. This integral $\left(I_{A_{\max }}\right)$ was calculated as:

$$
I_{A_{\max }}=\sum_{i=1}^{i=n} \frac{A_{\max (i)}+A_{\max (i+1)}}{2}\left(D_{i+1}-D_{i}\right)
$$

where $A_{\max (i)}$ is the photosynthetic capacity on measurement day $D_{i}$. The integral of the photosynthesis represents the area under the curve of the variations in measured photosynthesis over the entire 21-day cultivation test. This approach has been proven to be an effective tool in seedling physiology research (Lamhamedi et al. 2006; Myers 1988). We then tested the relationship between $I_{A_{\max }}$ and $R_{\mathrm{w}} / R_{\mathrm{t}}$ using the PROC REG procedure of SAS.

\section{Results}

\subsection{Apical index of injury following freeze treatments}

Apical index of injury $\left(I_{t}\right)$ was significantly affected by freezing temperature, the extent of the effect varying with sampling date (temperature $\times$ date: $P<0.0001$ ). Regardless of the date being considered, there was never a significant difference in $I_{\mathrm{t}}$ between the control temperature $\left(+4^{\circ} \mathrm{C}\right)$ and the $-4^{\circ} \mathrm{C}$ freezing temperature (Fig. 2a). On the first sampling date, there was a significant difference in $I_{\mathrm{t}}$ values between samples that were exposed to the control temperature $\left(+4^{\circ} \mathrm{C}\right)$ and those exposed to the freezing temperatures of $-8^{\circ} \mathrm{C}$ and colder (Fig. 2a). On the second and third sampling dates, the $I_{\mathrm{t}}$ values of the seedlings subjected to a $-8^{\circ} \mathrm{C}$ freeze, unlike those of the $-12^{\circ} \mathrm{C}$ and $-20^{\circ} \mathrm{C}$ treatments, were not significantly different from the $I_{\mathrm{t}}$ values of the seedlings exposed to $+4^{\circ} \mathrm{C}$ (Fig. 2a). It was necessary to wait until the fourth sampling date before there was no observed difference in the $I_{\mathrm{t}}$ values among the five artificial freezing temperature treatments (Fig. 2a).

\subsection{Root water loss following freeze treatments}

Root water loss (RWL) was significantly influenced by date and artificial freezing temperature. The effect of temperature differed among sampling dates (temperature $\times$ date: $P=$ 0.0025) (Fig. 2a). For the first two sampling dates, only seedlings subjected to the lowest temperature $\left(-18^{\circ} \mathrm{C}\right)$ exhibited RWL values significantly superior to those of the control temperature $\left(+4^{\circ} \mathrm{C}\right)$ (Fig. 2a). Beginning on the third sampling date (14 October), there was no longer a significant difference in RWL among the artificial freezing temperature treatments.

\subsection{Recovery of gas exchange variables in response} to freeze treatments

As autumn advanced and their level of hardening intensified, the seedlings were able to support progressively lower artificial freezing temperatures before their photosynthetic capacity was affected. The photosynthetic capacity $\left(A_{\max }\right)$ of the seedlings exposed to the control treatment $\left(+4^{\circ} \mathrm{C}\right) \mathrm{did}$ not differ significantly from that of the seedlings exposed to $\mathrm{a}-4^{\circ} \mathrm{C}$ freeze on any of the sampling dates. No significant 


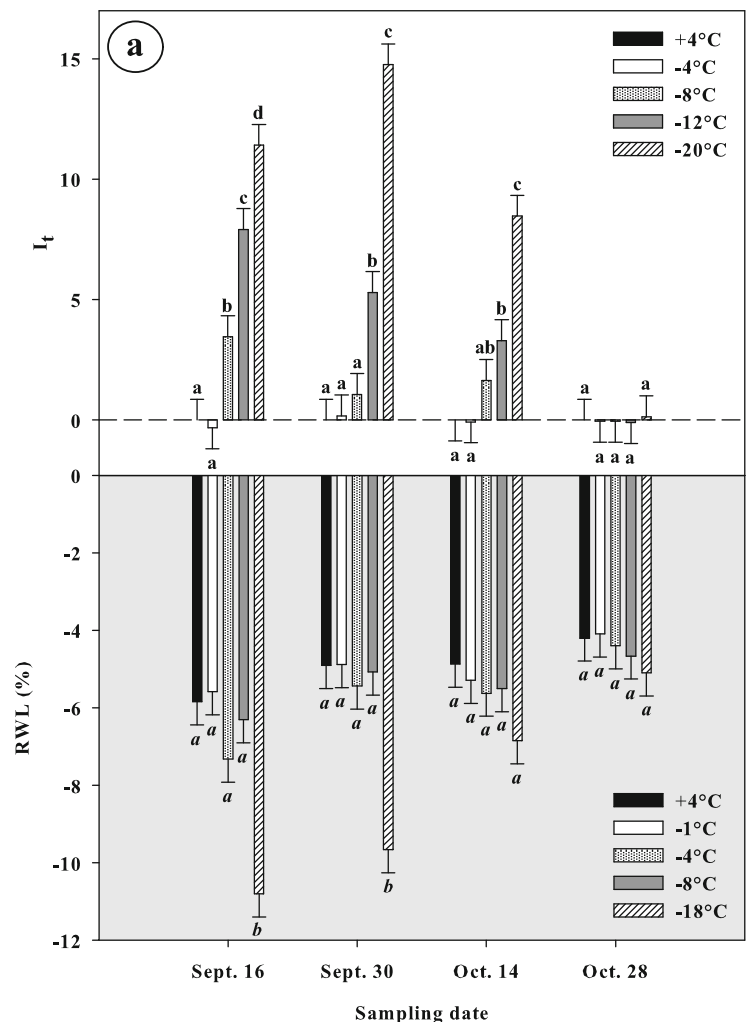

Fig. 2 Evolution of cold damage assessment variables of shoots and roots of 2-year-old white spruce seedlings following artificial freezing treatments $\left(+4^{\circ} \mathrm{C},-4^{\circ} \mathrm{C},-8^{\circ} \mathrm{C},-12^{\circ} \mathrm{C}\right.$, and $-20^{\circ} \mathrm{C}$ for shoot tissue and $+4^{\circ} \mathrm{C},-1^{\circ} \mathrm{C},-4^{\circ} \mathrm{C},-8^{\circ} \mathrm{C}$, and $-18^{\circ} \mathrm{C}$ for root tissue) on four sampling dates. Shoot and root cold damage were assessed a immediately after

difference in photosynthesis was found between the seedlings exposed to the control $\left(+4^{\circ} \mathrm{C}\right)$ and the $-8^{\circ} \mathrm{C}$ freeze treatment as of the second sampling date (30 September), between the control temperature $\left(+4^{\circ} \mathrm{C}\right)$ and the $-12^{\circ} \mathrm{C}$ treatment beginning on the third sampling date (14 October), and between the control temperature $\left(+4^{\circ} \mathrm{C}\right)$ and the $-20^{\circ} \mathrm{C}$ freeze treatment on the last sampling date $(28$ October) (Fig. 3).

Hardening level also influenced the dynamics of the recovery of gas exchange variables during each cultivation test. With respect to the first cultivation test (16 September sampling), only freezing temperature had a significant influence on the recovery of gas exchange $(P<0.0001)$. Each decrease in artificial freezing temperature was accompanied by a significant decrease in $A_{\max }$ (Fig. 3a). For a given temperature, $A_{\max }$ changed very little among the three measurement days (D2, D11, and D21) (Fig. 3a). For the second (30 September sampling) (Fig. 3b) and third (14 October sampling) cultivation tests (Fig. 3c), the effect of freezing temperature on the resumption of gas exchange varied as a function of the number of days after repotting. During the second cultivation test (30 September sampling), the $A_{\max }$ of the control seedlings $\left(+4^{\circ} \mathrm{C}\right)$, as well as

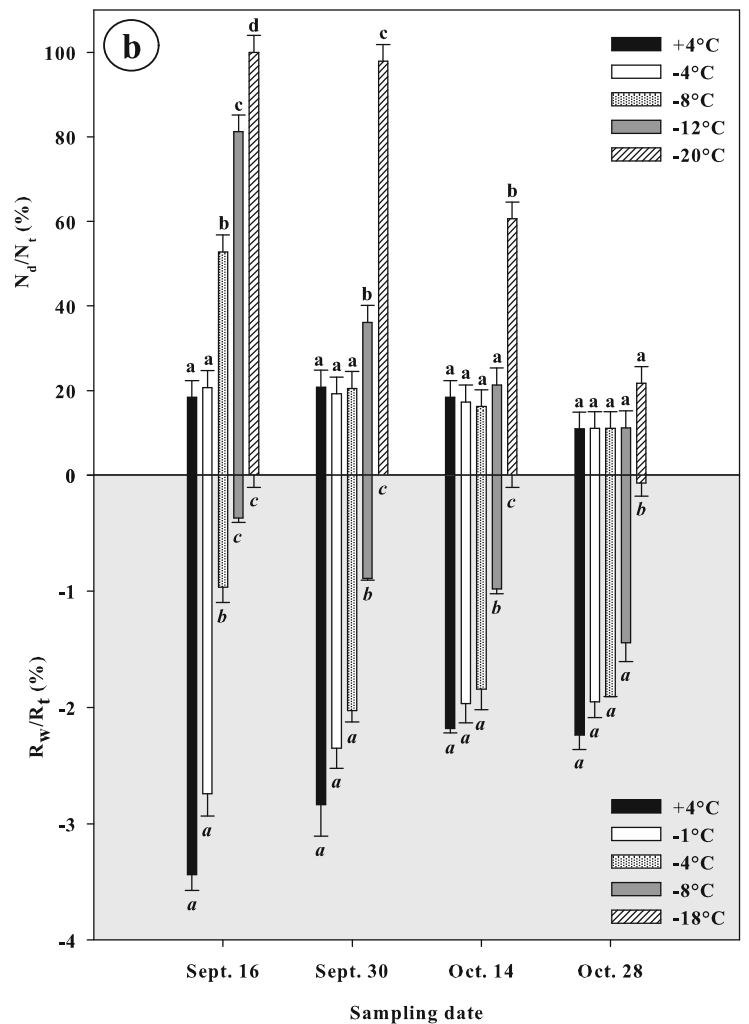

the freeze tests by, respectively, apical index of injury $\left(I_{t}\right)$ and root water loss (RWL) and $\mathbf{b}$ after a 21-day cultivation test by, respectively, shoot damage $\left(N_{\mathrm{d}} / N_{\mathrm{t}}\right)$ and initiation of new roots $\left(R_{\mathrm{w}} / R_{\mathrm{t}}\right)$. Each point represents the average of 24 seedlings. Bars represent the standard error associated with each point

those subjected to freeze of $-4^{\circ} \mathrm{C},-8^{\circ} \mathrm{C}$, or $-12^{\circ} \mathrm{C}$, decreased on the fourth day of gas exchange measurement (D21) to a level equivalent to that measured on the second day of measurement (D4) (Fig. 3b). For the third cultivation test (14 October sampling) (Fig. 3c), there was no significant difference among the seedlings subjected to the five temperatures the second day after repotting (D2) $(P=$ 0.0515 for the $F$ test comparing the five temperatures the second day after treatment). After this day, the $A_{\max }$ of the seedlings subjected to a $-20^{\circ} \mathrm{C}$ freeze declined to a level that was significantly lower than that measured in the seedlings subjected to the four other artificial freezing temperatures (Fig. 3c). For the last cultivation test (28 October sampling) (Fig. 3d), only measurement day had a significant effect on the recovery of gas exchange $(P=$ $0.0004)$ and $A_{\max }$ of the seedlings increased over the cultivation test period after being exposed to the five artificial freezing treatments.

The results of the analyses by date (not shown) for the ratio of substomatal $\mathrm{CO}_{2}$ concentration to ambient $\mathrm{CO}_{2}$ concentration $\left(C_{\mathrm{i}} / C_{\mathrm{a}}\right)$ resembled those obtained for photosynthetic capacity. Similar results were also obtained for the analyses of stomatal conductance to water vapor $\left(g_{\mathrm{sw}}\right)$. 


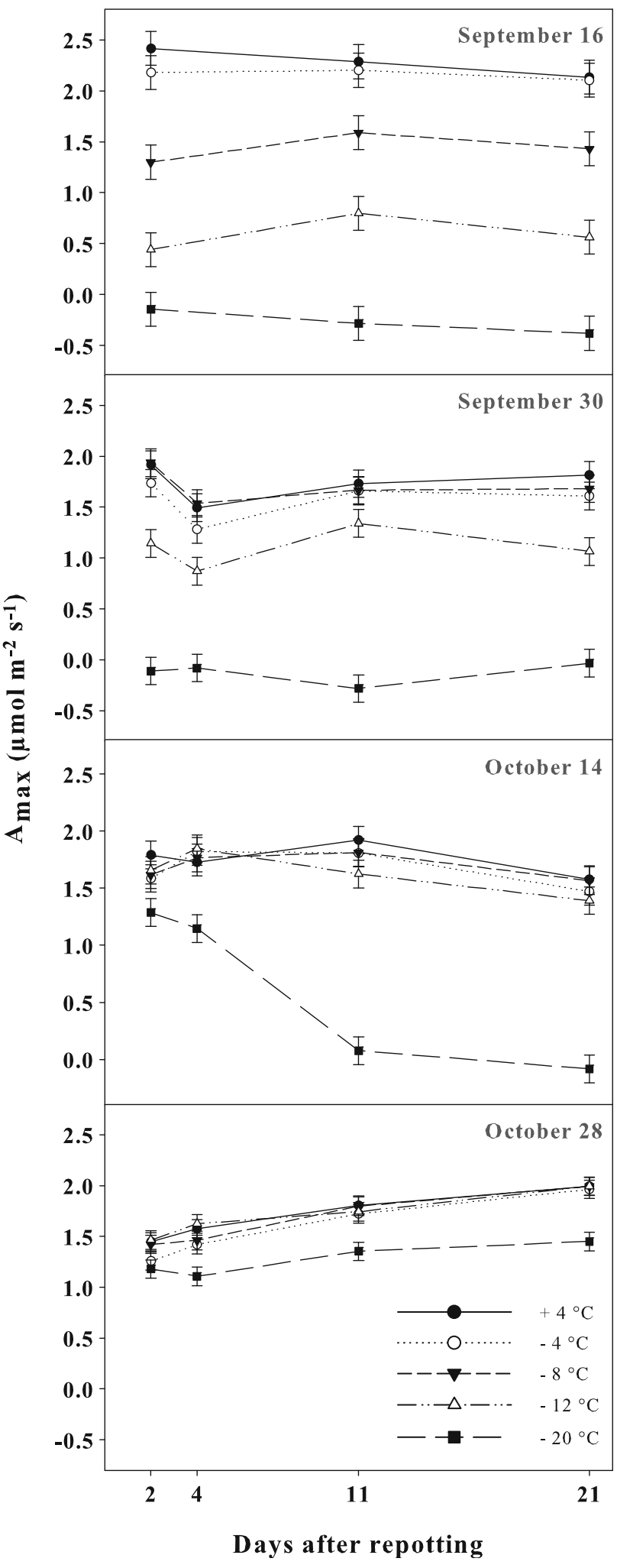

Fig. 3 Recovery of photosynthetic capacity of 2-year-old white spruce seedlings after being subjected to different artificial freezing treatments $\left(+4^{\circ} \mathrm{C},-4^{\circ} \mathrm{C},-8^{\circ} \mathrm{C},-12^{\circ} \mathrm{C}\right.$, and $-20^{\circ} \mathrm{C}$ for shoot tissue and $+4^{\circ} \mathrm{C},-1{ }^{\circ} \mathrm{C},-4^{\circ} \mathrm{C},-8^{\circ} \mathrm{C}$, and $-18^{\circ} \mathrm{C}$ for root tissue) on four sampling dates (16 and 30 September, 14 and 28 October 2002). Each point represents the average of 12 seedlings. Bars represent the standard error associated with each point
3.4 Evaluation of shoot damage in response to freeze treatments

The amount of shoot damage $\left(N_{\mathrm{d}} / N_{\mathrm{t}}\right)$ was significantly influenced by freezing temperature. The effect of temperature varied with respect to sampling date (temperature $\times$ date: $P<0.0001$ ) (Fig. 2b). Regardless of date, the control treatment $\left(+4^{\circ} \mathrm{C}\right)$ and the $-4^{\circ} \mathrm{C}$ freeze treatment were not significantly different (Fig. 2b). On the first sampling date (16 September), significant differences were found between the damage observed after exposure to the control treatment versus exposure to the $-8^{\circ} \mathrm{C},-12^{\circ} \mathrm{C}$, and $-20^{\circ} \mathrm{C}$ treatments (Fig. 2b). As of the second sampling date (30 September), the level of shoot damage under the $-8^{\circ} \mathrm{C}$ treatment, unlike the two lower freezing temperatures, did not differ significantly from that of the control treatment (Fig. 2b). On the third sampling date (14 October), seedlings subjected to freeze treatments of $-4^{\circ} \mathrm{C},-8^{\circ} \mathrm{C}$, and $-12^{\circ} \mathrm{C}$ did not sustain a significantly different amount of damage than those exposed to the control treatment (Fig. 2b). On the fourth sampling date ( 28 October), there was no significant difference in the amount of shoot damage as a result of the five different artificial freezing treatments (Fig. 2b).

Damage resulting from exposure to a given artificial freezing temperature diminished with each successive cultivation test as hardening intensified. Shoot damage $\left(N_{\mathrm{d}} / N_{\mathrm{t}}\right)$ in seedlings subjected to the lowest freezing temperature $\left(-20^{\circ} \mathrm{C}\right)$ were $100 \%, 97.9 \%, 60.6 \%$, and $21.7 \%$ at the end of the first, second, third, and fourth cultivation tests, respectively.

\subsection{Initiation of new roots after freeze treatments}

Both dry mass of new white roots $R_{\mathrm{w}}$ and the ratio of $R_{\mathrm{w}}$ to the dry mass of the total root system $\left(R_{\mathrm{t}}\right),\left(R_{\mathrm{w}} / R_{\mathrm{t}}\right)$ were influenced by freezing temperature. The effect of temperature varied with respect to sampling date (temperature $\times$ date: $P=0.0003$ ) (Fig. $2 b$ ). On the first sampling date (16 September), $R_{\mathrm{w}} / R_{\mathrm{t}}$ diminished significantly with temperature, beginning at $-4^{\circ} \mathrm{C}$ (Fig. 2b). On the second (30 September) and third (14 October) sampling dates, the ratio decreased significantly beginning at $-8^{\circ} \mathrm{C}$ (Fig. 2b). No new white roots were formed after a $-18^{\circ} \mathrm{C}$ freeze treatment, regardless of the degree of hardening (Fig. 2b).

3.6 Relationship between photosynthesis, new root initiation, and shoot damage

There was a significant relationship between the integral of the curve representing the evolution of photosynthetic activity during a cultivation test $\left(I_{A_{\max }}\right)$ and the natural 
logarithm of the $R_{\mathrm{w}} / R_{\mathrm{t}}$ ratio measured over the same growth period $(P<0.0001)$ :

$R_{\mathrm{W}} / R_{\mathrm{t}}=e^{\left(0.0159+0.02948 I_{A_{\max }}\right)}-1$

When shoot damage resulting from the different freeze treatments $\left(N_{\mathrm{d}} / N_{\mathrm{t}}\right)$ was taken into account, the $R_{\text {adjusted }}^{2}$ increased from 46.3 to $48.6 \%(P<0.0001)$ (Fig. 4).

Needle damage $\left(N_{\mathrm{d}} / N_{\mathrm{t}}\right)$ had an even greater effect on the initiation of new roots when the integral of photosynthetic capacity $\left(I_{A_{\max }}\right)$ was small. A $N_{\mathrm{d}} / N_{\mathrm{t}}$ ratio of $100 \%$ was necessary to decrease $R_{\mathrm{w}} / R_{\mathrm{t}}$ to $50 \%$ when $I_{A_{\max }}$ was close to its maximum value $\left(50 \mu \mathrm{mol} \mathrm{CO} \mathrm{CO}_{2} \mathrm{~m}^{-2} \mathrm{~s}^{-1} \mathrm{day}^{-1}\right)$. On the other hand, if $I_{A_{\max }}$ was small $\left(10 \mu \mathrm{mol} \mathrm{CO} \mathrm{Cm}^{-2} \mathrm{~s}^{-1}\right.$ day $\left.^{-1}\right)$, a $N_{\mathrm{d}} / N_{\mathrm{t}}$ ratio of $50 \%$ to $60 \%$ was enough to decrease $R_{\mathrm{w}} / R_{\mathrm{t}}$ to $50 \%$. On average, for a value of $I_{A_{\max }}$ equal to $50 \mu \mathrm{mol} \mathrm{CO}$ $\mathrm{m}^{-2} \mathrm{~s}^{-1}$ day $^{-1}$, each $10 \%$ increase in $N_{\mathrm{d}} / N_{\mathrm{t}}$ was accompanied by a decrease of $6 \%$ in $R_{\mathrm{w}} / R_{\mathrm{t}}$. Whereas, if $I_{A_{\max }}$ was $10 \mu \mathrm{mol}$ $\mathrm{CO}_{2} \mathrm{~m}^{-2} \mathrm{~s}^{-1}$ day $^{-1}$, each $10 \%$ increase in $N_{\mathrm{d}} / N_{\mathrm{t}}$ ratio was accompanied by an average decrease of $15 \%$ in $R_{\mathrm{w}} / R_{\mathrm{t}}$.

\section{Discussion}

After being subjected to artificial freezing tests on four sampling dates during the fall, 2-year-old white spruce

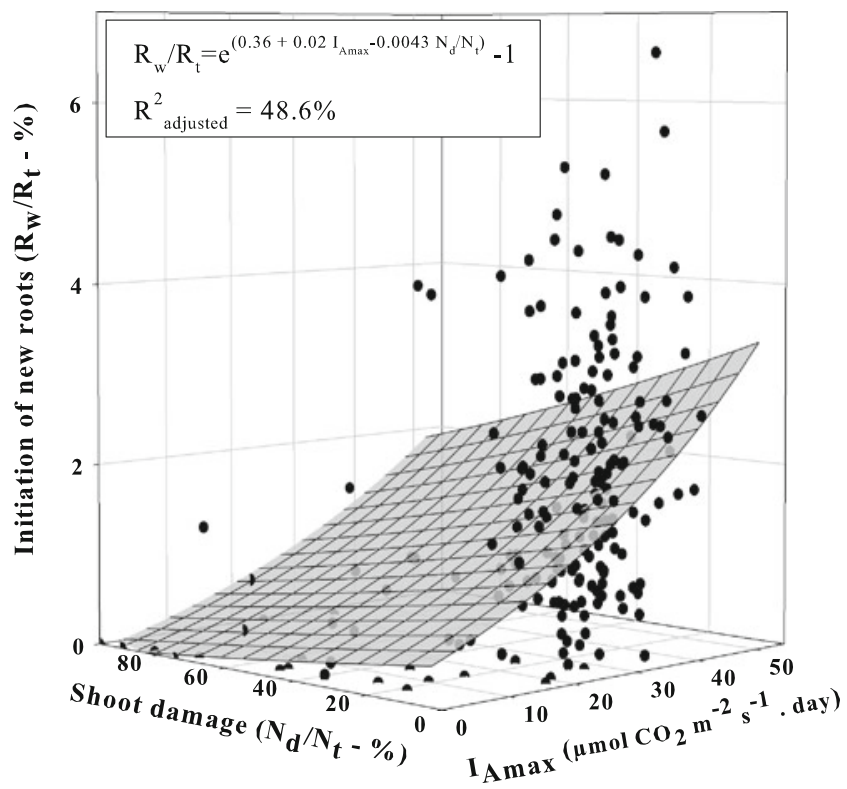

Fig. 4 Response surface for $R_{\mathrm{w}} / R_{\mathrm{t}}$ (new root dry mass/total root dry mass) as a function of $N_{\mathrm{d}} / N_{\mathrm{t}}$ (dry mass of dead needles/total needle dry mass) and the integral of photosynthesis $\left(I_{A_{\max }}\right)$ measured during the 21-day bioassay period under optimal growing conditions after the artificial freeze treatments $\left(+4^{\circ} \mathrm{C},-4^{\circ} \mathrm{C},-8^{\circ} \mathrm{C},-12^{\circ} \mathrm{C}\right.$, and $-20^{\circ} \mathrm{C}$ for shoot tissue and $+4^{\circ} \mathrm{C},-1^{\circ} \mathrm{C},-4^{\circ} \mathrm{C},-8^{\circ} \mathrm{C}$, and $-18^{\circ} \mathrm{C}$ for root tissue). Initiation of new roots and shoot damage were evaluated during the same bioassay period. The points $(n=240)$ indicate the distribution of the raw data measured for 3 seedlings per temperature per block per date seedlings, growing in forest nursery conditions, were compared for cold tolerance and recovery of gas exchange. The effect of artificial freezing treatments on the photosynthetic capacity of the seedlings varied with freeze intensity and degree of needle hardening. The mass of new roots formed over a 21-day cultivation test period following the freeze tests was positively related to the seedling's photosynthetic capacity and negatively related to the proportion of damaged needles $\left(R^{2}=48.6 \%\right)$. Almost no initiation of white roots was observed when shoot damage exceeded $50 \%$. This impact of needle cold damage on root growth increased as seedling photosynthetic capacity decreased.

The reduction in photosynthetic capacity with decreasing freezing temperature may result from cold damage to the root system, the foliage, or both. Root system damage, identified through root water loss tests, reduces the seedling's capacity to absorb water and nutrients. This, in turn, may reduce photosynthesis (Coursolle et al. 2002). However, the effect of the freeze treatments on both substomatal cavity $\mathrm{CO}_{2}$ concentration and stomatal conductance to water vapor resembled that observed for photosynthetic capacity, suggesting that cold damage to the foliage is mostly likely responsible for the reduction in photosynthesis. Since the freeze treatments were administered in darkness, the initial direct damage was probably due to cold damage to the seedling cell membranes (Gillies and Binder 1996).

The gradual decrease in temperature necessary to cause damage over the duration of the experiment illustrates the ability of the cell membranes and photosynthetic apparatus of evergreen species to acclimate to low winter temperatures and reduce the risks of photoinhibition during the overwintering period (Öquist and Huner 2003). This acclimation consists of, among other things, an aggregation of the chloroplasts, thus reducing the quantity of light received by the seedling (Alves et al. 2002). Senser et al. (1975) observed such an aggregation in Norway spruce (Picea abies (L.) Karst) needles during hardening.

In the BIOMASS model, which is used to model the carbon cycle in the boreal forest, an autumn frost of $-5^{\circ} \mathrm{C}$ or colder is considered to irreversibly reduce photosynthetic capacity by $10 \%$ (Bergh et al. 1998). Our results contradict this postulate because, during the current study, the photosynthetic capacity of the 2-year-old white spruce seedlings exposed to an artificial freeze of $-4^{\circ} \mathrm{C}$, administered in darkness, was no different than that of the control seedlings maintained at $+4^{\circ} \mathrm{C}$. In addition, on 30 September, 14 October, and 28 October, the seedlings exposed to artificial freezes of as cold as $-8^{\circ} \mathrm{C},-12^{\circ} \mathrm{C}$, and $-20^{\circ} \mathrm{C}$, respectively, did not have significantly different photosynthetic capacities than those of the control seedlings. Gaumont-Guay et al. (2003) observed this same phenomenon in 3-year-old black spruce seedlings 
and estimated that, below a threshold temperature of $-3.8^{\circ} \mathrm{C}$, nonacclimatized 3-year-old black spruce seedlings would be adversely affected. However, they also showed that, with an accumulation of cold degree-days during autumn hardening, the photosynthetic apparatus was capable of tolerating progressively lower temperatures and found that the reduction in photosynthetic capacity of these seedlings was not significantly different from those of the seedlings subjected to the $+2^{\circ} \mathrm{C}$ control treatment. Our results also show a relationship between hardening of needle tissue and a decrease in photosynthetic capacity in white spruce seedlings. Thereby, the photosynthetic capacity of the control seedlings decreased from a value of $2.41 \mu \mathrm{mol} \mathrm{m} \mathrm{m}^{-2} \mathrm{~s}^{-1}$ at the beginning of the first cultivation test to a value of $1.44 \mu \mathrm{mol} \mathrm{m}^{-2} \mathrm{~s}^{-1}$ at the beginning of the last cultivation test, which represents a decrease of $40 \%$ in the photosynthetic capacity.

New white roots are initiated in spruce seedlings, in part, from the products of current photosynthesis. This is evident by the significant relationship between white root initiation and photosynthetic rate in the current study. van den Driessche (1987) and Pellicier et al. (2000) arrived at the same conclusion for different coniferous species [Larix $\mathrm{x}$ europlepis, Pseudotsuga menziesii (Mirb.) Franco, and Picea sitchensis (Bong.) Carr.]. When air temperatures permit a positive photosynthetic rate and soil temperature remains above freezing (Bigras and Dumais 2005), the initiation of white roots seems to be possible if a large proportion of the seedling's needles remain photosynthetically active after being exposed to episodes of freezing. Almost no initiation of white roots was observed when shoot damage exceeded $50 \%$. The proportion of photosynthetically active needles becomes a more important factor as the photosynthetic capacity of the seedling decreases (Fig. 4). Moreover, cultural practices and environmental factors that influence a seedling's photosynthetic capacity may have an effect on the initiation of new roots. In some cases, however, the initiation of new white roots may be inhibited by the presence of more important sinks for current photosynthates (Waring and Pitman 1985). For example, in our study, the absence of the recovery of root growth after the roots were exposed to a freeze of $-18^{\circ} \mathrm{C}$ on the last sampling date ( 28 October) may have been the result of the accumulation of a sufficient number of cold degree-days to lift primary dormancy (Fig. 1), so that when the seedlings were placed under optimal growing conditions, they broke bud (Lamhamedi et al. 2005).

When photosynthesis is high, high values of $R_{\mathrm{w}} / R_{\mathrm{t}}$ can only be observed in the absence of needle damage and of a stronger sink in other parts of the seedling. To observe high $R_{\mathrm{w}} / R_{\mathrm{t}}$, there also must be an intact functional phloem pathway from shoot to root, root tips must be capable of growing, and all the metabolic pathways that support root respiration must be functional (Ritchie and Tanaka 1990; Simpson and Ritchie 1996). Roots are less coldtolerant than shoots and harden later in the fall (Bigras et al. 2001). Consequently, undamaged shoots can be observed following freezing temperature values that damage roots. In the present study, cold damages to roots immediately after the freezing treatment were evaluated by root water loss. According to Coursolle et al. (2000), this method is only able to detect moderate to high root damage levels. This implies that root damage could have gone undetected and impaired the initiation of new roots in seedlings with no damaged shoots and high photosynthesis capacity (Fig. 4). Another possible source of the observed $R_{\mathrm{w}} / R_{\mathrm{t}}$ variation not explained by the response surface represented in Fig. 4 is the genetic variability previously observed for root growth potential at family (Nambiar et al. 1982) or clonal (Lamhamedi et al. 2000) levels.

Despite these few unexplained results, our study suggests that autumn cold damage to needles directly affects the root growth of 2-year-old white spruce seedlings. This finding emphasizes the importance of maintaining seedlings in an environment favorable for photosynthesis during the fall to promote root growth and of protecting needles against potential cold damage in the early autumn.

Acknowledgements This project was carried out in collaboration with Pampev Inc. (Saint-Louis-de-Blandford, Québec), the Ministère des Ressources naturelles et de la Faune (MRNF) du Québec, and the Laurentian Forestry Centre (Canadian Forest Service). The authors thank Denis Lavallée, Mario Renaud, Claude Fortin, Marie-Claude Martel, Marc-André Giasson, Marie Coyea, and the staff of the Laboratoire de chimie organique et inorganique (MRNF) for their technical assistance. The assistance of Drs. Carole Coursolle and William Parsons of the Faculté de foresterie, de gérographie et de géomatique and Emmanuelle Reny-Nolin of the Département de mathématiques et de statistique at Université Laval during manuscript preparation and statistical analyses was appreciated.

Funding Financial support to Hank Margolis for this project was provided by the Fonds québécois de la recherche sur la nature et les technologies (FQRNT) (project: 2001-FF-79130) and to Dr. Mohammed Lamhamedi by the MRNF (projects: 3071 and 3076).

\section{References}

Bergh J, McMurtrie RE, Linder S (1998) Climatic factors controlling the productivity of Norway spruce: a model-based analysis. For Ecol Manag 110:127-139

Bernier-Cardou M, Bigras FJ (2001) The analysis of cold hardiness experiments. In: Bigras FJ, Colombo SJ (eds) Conifer cold hardiness. Kluwer Academic, Dordrecht, pp 403-435

Bigras FJ, D'Aoust AL (1992) Hardening and dehardening of shoots and roots of containerized black spruce and white spruce seedlings under short and long days. Can J For Res $22: 388-396$

Bigras FJ, D'Aoust AL (1993) Influence of photoperiod on shoot and root frost tolerance and bud phenology of white spruce seedlings (Picea glauca). Can J For Res 23:219-228 
Bigras FJ, Dumais D (2005) Root-freezing damage in the containerized nursery: impact on plantation site - a review. New Forest 30:167-184

Bigras FJ, Ryyppö A, Lindström A, Stattin E (2001) Cold acclimation and deacclimation of shoots and roots of conifer seedlings. In: Bigras FJ, Colombo SJ (eds) Conifer cold hardiness. Kluwer Academic, Dordrecht, pp 57-88

Carles S, Lamhamedi MS, Stowe DC, Margolis HA, Bernier PY, Veilleux L, Fecteau B (2008) Frost tolerance of two-year-old Picea glauca seedlings grown under different irrigation regimes in a forest nursery. Scand J For Res 23:137-147

Colombo SJ, Webb DP, Glerum C (1984) Operational monitoring of frost hardiness for guiding the extended greenhouse culture method of hardening spruce container stock. Ontario Ministry of Natural Resources, Peterborough

Coursolle C, Bigras FJ, Margolis HA (2000) Assessment of root freezing damage of two-year-old white, black spruce and jack pine seedlings. Scand J For Res 15:343-353

Coursolle C, Bigras FJ, Margolis HA (2002) Effects of root freezing on the physiology and growth of Picea glauca, Picea mariana and Pinus banksiana seedlings under different soil moisture regimes. Scand J For Res 17:206-217

da CA Alves PL, Magalhães ACN, Barja PR (2002) The phenomenon of photoinhibition of photosynthesis and its importance in reforestation. Bot Rev 68:193-208

Flint HL, Boyce BR, Beattie DJ (1967) Index of injury-a useful expression of freezing injury to plant tissues as determined by the electrolytic method. Can J Plant Sci 47:229-230

Gaumont-Guay D, Margolis HA, Bigras FJ, Raulier F (2003) Characterizing the frost sensitivity of black spruce photosynthesis during cold acclimation. Tree Phys 23:301-311

Gillies SL, Binder WD (1996) The effect of sub-zero temperatures in the light and dark on cold-hardened, dehardenend and newly flushed white spruce (Picea glauca [Moench.] Voss) seedlings. New Forest 13:91-104

Girard D, Gagno J, Langlois CG (2001) PLANTEC : un logiciel pour gérer la fertilisation des plants dans les pépinières - Note de recherche forestière $\mathrm{n}^{\circ} 111$. In. Gouvernement du Québec Ministère des Ressources naturelles - Forêt Québec - Direction de la recherche forestière, Sainte Foy

Grossnickle SC (2000) Ecophysiology of northern spruce species: the performance of planted seedlings. NRC Research Press, Ottawa

Grossnickle SC (2005) Importance of root growth in overcoming planting stress. New Forest 30:273-294

Islam MA, Apostol KG, Jacobs DF, Dumroese RK (2009) Fall fertilization of Pinus resinosa seedlings: nutrient uptake, cold hardiness, and morphological development. Ann For Sci 66:704. p1-704.p9

Johnson-Flanagan AM, Owens JN (1985) Root growth and root growth capacity of white spruce (Picea glauca (Moench) Voss) seedlings. Can J For Res 15:625-630

Lamhamedi MS, Chamberland H, Bernier PY, Tremblay FM (2000) Clonal variation in morphology, growth, physiology, anatomy and ultrastructure of container-grown white spruce somatic plants. Tree Phys 20:869-880

Lamhamedi MS, Lambany G, Margolis HA, Renaud M, Veilleux L, Bernier PY (2001) Growth, physiology, and leachate losses in Picea glauca seedlings $(1+0)$ grown in air-slit containers under different irrigation regimes. Can J For Res 31:1968-1980

Lamhamedi MS, Renaud M, Veilleux L (2005) Élaboration des seuils de tolérance au gel des plants d'épinette blanche $(1+0)$ en pépinière forestière selon les régions écologiques du Québec - Mémoire de recherche $\mathrm{n}^{\mathrm{o}} 147$. In. Gouvernement du Québec - Ministère des Ressources naturelles - Forêt Québec - Direction de la recherche forestière, Sainte Foy
Lamhamedi MS, Labbé L, Margolis HA, Stowe DC, Blais L, Renaud M (2006) Spatial variability of substrate water content and growth of white spruce seedlings. Soil Sci Soc Am J 70:108-120

Landis TD (2010) Chapter 1. The target plant concept. In: Landis TD (ed) The container tree nursery manual-vol. 7. Seedling processing, storage, and outplanting. US Department of Agriculture, Forest Service, Agric. Handbk. 674, Washington, DC, pp 116

Levitt J (1980) Responses of plants to environmental stresses, vol I. Chilling, freezing, and high temperature stresses, 2nd edn. Academic, New York

Littell RC, Milliken GA, Stroup WW, Wolfinger RD (1996) SAS system for mixed models. SAS Institute Inc., Cary

Margolis HA (1987) Seedling production and reforestation in Quebec. J For 85:39-43

Milliken GA, Johnson DE (1984) Analysis of messy data, volume1: designed experiments. Van Nostrand Reinhold Company, New York

Müller MJ (1982) Selected climatic data for a global set of standard stations for vegetation science. Dr. W. Junk, The Hague

Myers BJ (1988) Water stress-integral - a link between short-term stress and long-term growth. Tree Phys 4:315-323

Nambiar EKS, Cotterill PP, Bowen GD (1982) Genetic differences in the root regeneration of radiata pine. J Exp Bot 33:170-177

Nienstaedt H, Zasada JC (1990) Picea glauca (Moench) Voss white spruce. In: Burns RM, Honkala BH (eds) Silvics of North America, vol. 1. Conifers-agriculture handbook no. 654. Dept. of Agriculture, United States, pp 204-226

Oliet JA, Salazar JM, Villar R, Robredo E, Vallardares F (2011) Fall fertilization of Holm oak affects $\mathrm{N}$ and $\mathrm{P}$ dynamics, root growth potential, and post-planting phenology and growth. Ann For Sci 68:647-656

Öquist G, Huner NPA (2003) Photosynthesis of overwintering evergreen plants. Annu Rev Plant Biol 54:329-355

Pellicier V, Guehl JM, Daudet FA, Cazet M, Riviere LM, Maillard P (2000) Carbon and nitrogen mobilization in Larix x eurolepis leafy stem cuttings assessed by dual ${ }^{13} \mathrm{C}$ and ${ }^{15} \mathrm{~N}$ labeling: relationships with rooting. Tree Phys 20:807-814

Ritchie GA (1990) A rapid method for detecting cold injury in conifer seedling root systems. Can J For Res 20:26-30

Ritchie GA, Tanaka Y (1990) Chapter 4-root growth potential and the target seedling. In: Rose R, Campbell SJ, Landis TD (eds) Western forest nursery association. US Department of Agriculture, Forest Service, Rocky Mountain Forest and Range Experiment Station, Roseburg, pp 37-51

Sakai A, Larcher W (1987) Frost survival of plants. Springer, New York

Senser M, Schötz F, Beck E (1975) Seasonal change in structure and function of spruce chloroplasts. Planta 126:1-10

Silim SN, Lavender DP (1994) Seasonal patterns and environmental regulation of frost hardiness in shoots of seedlings of Thuja plicata, Chamaecyparis nootkatensis, and Picea glauca. Can J Bot 72:309-316

Simpson DG, Ritchie GA (1996) Does RGP predict field performance? A debate. New Forest 13:249-273

Stowe DC, Lamhamedi MS, Carles S, Fecteau B, Margolis HA, Renaud M, Bernier PY (2010) Managing irrigation to reduce nutrient leaching in containerized white spruce seedling production. New Forest 40:185-204

Timmis R, Flewelling J, Talbert C (1994) Frost injury prediction model for Douglas-fir seedlings in the Pacific Northwest. Tree Phys 14:855-869

van den Driessche R (1987) Importance of current photosynthate to new root growth in planted conifer seedlings. Can J For Res $17: 776-782$ 
Veilleux P, Bonneau A, Girard J-P, Labrecque L, Lever R, Lortie J, Perreault F-N, Tourigny M (2010) Guide terrain. Inventaire de qualification des plants résineux cultivés en récipient, document de travail, livraison 2010. Direction générale des pépinières et des stations piscicoles, ministère des Ressources naturelles et de la Faune, Québec

Vidaver W, Binder W, Brooke RC, Lister GR, Toivonen PMA (1989) Assessment of photosynthetic activity or nursery-grown Picea glauca using an integrating fluorometer to monitor variable chlorophyll fluorescence. Can J For Res 19:1478-1482

Waring RH, Pitman GB (1985) Modifying lodgepole pine stands to change susceptibility to mountain pine beetle attack. Ecology 66:889-897

Zhu XB, Cox RM, Bourque C-PA, Arp PA (2002) Thaw effect on cold-hardiness parameters in yellow birch. Can J Bot 80:390 398 